\title{
Precatórios: o Caminho do "Meio"
}

Nelson Jobim'

\section{Introdução}

Um dos maiores problemas político-constitucionais após a promulgação da Constituição de 1988 tem sido o tema dos precatórios judiciais.

A questão está na sua íntima relação com os limites de recursos financeiros e com os gastos públicos.

O precatório é importante instrumento constitucional que disciplina a forma pela qual as decisões judiciais condenatórias do Poder Público serão processadas e cumpridas.

A interpretação do art. 100 da CF é diretamente vinculada à necessidade de se criar meio político-jurídico que tente conformar duas preocupaçōes igualmente importantes.

De um lado, o dever constitucional de o Estado saldar seus débitos e fazer cumprir as decisões judiciais condenatórias.

De outro lado, a necessidade de se investir de acordo com os programas políticos vencedores nos certames eleitorais no contexto da escassez de recursos.

Quando os recursos financeiros são abundantes, o não pagamento de um precatório somente pode ser resolvido no quadro da configuração de eventual dolo por parte do administrador.

Entretanto, quando há pouco dinheiro e esses mínimos recursos já têm destinação constitucional previamente fixada, o problema transcende - em muito - os

Advogado. Ex Presidente do Supremo Tribunal Federal e do Conselho Nacional de Justiça. 
limites dos contornos estritamente jurídicos, passando a ser de natureza políticoinstitucional.

Envolve a administração dos recursos públicos, governabilidade, viabilidade financeira dos entes federativos e, mesmo, autonomia de gestão dos governos estaduais.

Se o problema está longe de ser meramente jurídico, as eventuais soluçōes a serem propostas não podem ser também de natureza apenas jurídica.

Uma interpretação "genial" do texto constitucional ou a criação de novas sanções para o Poder Executivo inadimplente, por si só, não resolve a grave crise financeira que o tema dos precatórios torna evidente.

Também não há espaço para soluções "maniqueístas" ou milagrosas de quem ache que somente uma das partes - devedor ou credor - tem absoluta razão.

Não se pode partir do pressuposto de que as preocupações externadas por devedor ou credor são, de antemão, ilusórias, fantasiosas ou mesmo mentirosas.

A busca de uma solução para o problema passa pela captação do contexto político e econômico.

Hão de ser verificados os limites de incidência e a aplicação do art. 100 da Constituição, que considere, de forma igual, as preocupações legítimas de devedores e credores.

Com essa observação não se quer dizer que haja um problema no próprio instrumento do precatório como forma de disciplinar o pagamento de despesas públicas a partir de previsões orçamentárias e o cumprimento de decisões judiciais com a observância dos princípios da igualdade e impessoalidade.

Desde suas primeiras formulações constitucionais - especialmente após a Constituição de $1934^{2}$ - o precatório se constitui em importante mecanismo de pagamento das dívidas públicas.

Sua criação se baseou no compromisso de se construírem fórmulas de pagamento judicial de dívidas que superassem as práticas pessoais e clientelistas utilizadas na República Velha.

A história da utilização dos precatórios é, por isso, uma história de criação de mecanismos que garantissem a impessoalidade necessária ao trato da coisa pública.

\footnotetext{
2 Constituição de 1934:
}

Art. 182. Os pagamentos devidos pela Fazenda federal, em virtude de sentença judiciária, far-se-ão na ordem de apresentaçāo dos precatórios e à conta dos créditos respectivos, sendo vedada a designação de caso ou pessoas nas verbas legais.

Parágrafo único. Estes créditos serāo consignados pelo Poder Executivo ao Poder Judiciário, recolhendo-se as importâncias ao cofre dos depósitos públicos. Cabe ao Presidente da Corte Suprema expedir as ordens de pagamento, dentro das forças do depósito, e, a requerimento do credor que alegar preterição da sua precedência, autorizar o seqüestro da quantia necessária para o satisfazer, depois de ouvido o Procurador-Geral da República. 
Exemplo dessa tendência está na sucessão de alteraçōes constitucionais que foram realizadas com o intuito de aprimorar o instrumento:

(a) em 1934, fixa-se a ordem cronológica de apresentação para o pagamento dos precatórios e a vedação expressa de designação pessoal para a destinação dos recursos;

(b) em $1946,{ }^{3}$ a ampliação do instrumento para as Fazendas Estaduais e Municipais, a abertura de dotação orçamentária específica e a necessária oitiva do Chefe do Ministério Público no caso de requisição de seqüestro de verba;

(c) em 1967, ${ }^{4}$ a obrigatoriedade de a União, Estados e Municípios incluírem em seus orçamentos a previsão necessária;

(d) em 1988,5 a necessidade de se conservar, não o valor histórico do precatório, mas o seu valor real por meio de correção monetária.

\footnotetext{
Constituição de 1946:

Art 204. Os pagamentos devidos pela Fazenda federal, estadual ou municipal, em virtude de sentença judiciária, far-se-ão na ordem de apresentaçāo dos precatórios e à conta dos créditos respectivos, sendo proibida a designaçāo de casos ou de pessoas nas dotaçōes orçamentárias e nos créditos extra-orçamentários abertos para esse fim.

Parágrafo único. As dotações orçamentárias e os créditos abertos serão consignados ao Poder Judiciário, recolhendo-se as importâncias à repartição competente. Cabe ao Presidente do Tribunal Federal de Recursos ou, conforme o caso, ao Presidente do Tribunal de Justiça expedir as ordens de pagamento, segundo as possibilidades do depósito, e autorizar, a requerimento do credor preterido no seu direito de precedência, e depois de ouvido o chefe do Ministério Público, o seqüestro da quantia necessária para satisfazer o débito.
}

Constituição de 1967:

Art 112. Os pagamentos devidos pela Fazenda Federal, Estadual ou Municipal, em virtude de sentença judiciária, far-se-ão na ordem de apresentaçāo dos precatórios e à conta dos créditos respectivos, proibida a designação de casos ou de pessoas nas dotaçōes orçamentárias e nos créditos extra-orçamentários abertos para esse fim.

$\$ 1^{*}$ É obrigatória a inclusāo, no orçamento das entidades de direito público, de verba necessária ao pagamento dos seus débitos constantes de precatórios judiciários, apresentados até primeiro de julho.

$\$ 2$ As dotaçōes orçamentárias e os créditos abertos serāo consignados ao Poder Judiciário, recolhendo-se as importâncias respectivas à repartiçāo competente. Cabe ao Presidente do Tribunal, que proferiu a decisão exeqüenda determinar o pagamento, segundo as possibilidades do depósito, e autorizar, a requerimento do credor preterido no seu direito de precedencia, e depois de ouvido o chefe do Ministério Público, o seqüestro da quantia necessária à satisfaçāo do débito.

5 Constituiçāo de 1988 (redação original):

Art. 100 À exceção dos créditos de natureza alimentícia, os pagamentos devidos pela Fazenda Federal, Estadual ou Municipal, em virtude de sentença judiciária, far-se-āo exclusivamente na ordem cronológica de apresentação dos precatórios e à conta dos créditos respectivos, proibida a designação de casos ou de pessoas nas dotaçōes orçamentárias e nos créditos adicionais abertos para este fim.

$\$ 1^{\circ}$ É obrigatória a inclusão, no orçamento das entidades de direito público, de verba necessária ao pagamento de seus débitos constantes de precatórios judiciários, apresentados até $1^{\circ}$ de julho, data em que terão atualizados seus valores, fazendo-se o pagamento até o final do exercício seguinte.

$\$ 2$ As dotaçōes orçamentárias e os créditos abertos serão consignados ao Poder Judiciário, recolhendo-se as importâncias respectivas à repartiçāo competente, cabendo ao Presidente do Tribunal que proferir a decisão exequienda determinar o pagamento, segundo as possibilidades do depósito, e autorizar, a requerimento do credor e exclusivamente para o caso de preterimento de seu direito de precedência, o seqüestro da quantia necessária à satisfação do débito. 
Observa-se que, do ponto de vista jurídico, houve indubitável aprimoramento do instituto.

Entretanto, do ponto de vista político, houve uma perigosa defasagem na forma como esse instituto se relacionaria com os contextos político-econômico e como se daria tratamento aos problemas financeiros centrais do Brasil. Assim, chega-se à situação atual com a disciplina dos precatórios devidamente regulamentados no art. 100 da Constituição Federal e sob aplausos dos juristas nos primeiros anos de vigência da nova Constituição.

Embora o artigo 100 da CF estabeleça que os precatórios expedidos e incluídos na lei orçamentária deverão ser pagos no ano seguinte, mediante ordem cronológica de sua apresentação, nota-se que quase a totalidade dos Estados e grande parte dos municípios brasileiros estão descumprindo tal mandamento constitucional.

Este artigo procura fazer uma análise do regime de precatórios no Brasil, aborda a evolução histórico-legal após a CF de 1988, a situação atual e as possíveis soluçōes para o crescente incremento no volume de precatórios não pagos.

\section{Um breve histórico da legislaçāo de precatórios no período pós-88}

O atraso no pagamento de precatórios é uma questão antiga no Brasil e mesmo antes da Constituição de 1988 já era significativo o montante de precatórios em atraso.

A instabilidade monetária e os sucessivos Planos Econômicos acentuaram a questão.

A partir de 1986, em razão da discussão sobre a aplicação de índices de atualização monetária, surgiu uma avalanche de ações contra os órgãos públicos que redundaria em novos volumes de precatórios a serem pagos.

O problema já antes de 1988 se apresentava com forte conotaçāo administrativo-política, embora se tentasse aprimorar o instrumento jurídico do precatório para dar solução ao contexto financeiro que se apresentava.

Tanto assim que o art. 33 do $\mathrm{ADCT}^{6}$ já previa, para os precatórios não pagos na data da promulgação da Constituiçāo, um prazo de oito anos para efetivar tais pagamentos.

\footnotetext{
6 "Art. 33. Ressalvados os créditos de natureza alimentar, o valor dos precatórios judiciais pendentes de pagamento na data da promulgação da Constituição, incluido o remanescente de juros e correção monetária, poderá ser pago em moeda corrente, com atualização, em prestaçōes anuais, iguais e sucessivas, no prazo máximo de oito anos, a partir de $1^{\circ}$ de julho de 1989 , por decisāo editada pelo Poder Executivo até cento e oitenta dias da promulgação da Constituição.

Parágrafo único. Poderāo as entidades devedoras, para o cumprimento do disposto neste artigo, emitir, em cada ano, no exato montante do dispêndio, títulos de dívida pública não computáveis para efeito do limite global de endividamento."
} 
Era uma tentativa clara de proporcionar maior fôlego às finanças públicas.

A solução de transição de 1988 pareceria ser eficaz.

Ninguém supunha que, ao permitir que estados e municípios pudessem emitir títulos da dívida pública para o pagamento de precatórios, isto resultaria na utilização indevida dos recursos públicos.

O mecanismo de emissão de dívida pública se viu inviabilizado por escândalos que levariam à CPI dos precatórios em 1997.

Os problemas de pagamentos persistiam e novas alternativas foram apresentadas.

A primeira modificação no regime de precatórios veio em 16 de dezembro de 1998.

A EC $\mathrm{n}^{\circ} 20$ instituiu a figura do pequeno valor (art. 100, $\$ 3^{\circ}$ ), ${ }^{7}$ excluindo-a no regime de precatórios.

Foi a forma de evitar que precatórios com valores baixos e de natureza geralmente alimentícia fossem obrigados a aguardar a lenta evolução da ordem cronológica de pagamentos.

Dois anos mais tarde (13-9-2000), a EC no 30 altera a redação do art. 100 da Constituição e acrescenta o art. 78 do ADCT.

O novo texto trouxe uma série de alteraçōes no regime dos precatórios:

(a) o $\mathbb{1} 1^{-}-A$ conceituou os débitos de natureza alimentícia;

(b) o $\mathbb{S} 2^{\circ}$ destacou que as dotações orçamentárias e os créditos abertos seriam consignados diretamente ao Poder Público;

(c) o $\mathbb{S} 3^{\circ}$ ampliou a regra da exclusão do pagamento das obrigações de pequeno valor da disciplina dos precatórios para o Distrito Federal;

(d) $\circ \$ 4^{\circ}$ autorizou que lei poderia fixar valores distintos a título de obrigações de pequeno valor de acordo com as diferentes capacidades das entidades de direito público;

(e) $\$ 5^{\circ}$ instituiu a figura do crime de responsabilidade para o Presidente do Tribunal no caso de retardamento ou tentativa de frustar a liquidação regular de precatórios.

A EC n 30/2000 acrescentou, ainda, o art. 78 no ADCT.

\footnotetext{
Constituição de 1988 (com a redaçāo da EC n² 20/1998):

Art. 100 .

[...]

\$3" O disposto no caput deste artigo, relativamente à expediçāo de precatórios, nāo se aplica aos pagamentos de obrigações definidas em lei como de pequeno valor que a Fazenda Federal, Estadual, Distrital ou Municipal deva fazer em virtude de sentença judicial transitada em julgado.
} 
Determinou que os precatórios pendentes de pagamento na data da promulgação da emenda - com exceção das obrigações de pequeno valor, dos precatórios de natureza alimentícia, dos precatórios do art. 33 do ADCT e dos precatórios que já tivessem recursos liberados - poderiam ser pagos no prazo máximo de 10 anos.

Os créditos decorrentes de salários, vencimentos, pensões e suas complementações, benefícios previdenciários e indenizações por morte ou invalidez, não estavam submetidos à ordem cronológica de apresentação dos precatórios.

O SUPREMO, a partir da Ação Direta de Inconstitucionalidade n 47 , declarou a constitucionalidade do Decreto n ${ }^{0} 29.463 / 98$ do Estado de São Paulo sob o argumento de que os créditos de natureza alimentar, embora tenham precedência sobre os demais, devem ter o pagamento efetuado mediante precatório.

De acordo com a decisão do SUPREMO, não se acham dispensados do regime de precatórios os créditos de natureza alimentícia, nem contraria o art. $100 \mathrm{da}$ Constituição serem eles dispostos em ordem própria, com prioridade sobre os de natureza geral (ADI 47, rel. Min. Octávio Gallotti, 22-10-1992).

O primeiro instituto legal a tratar acerca da questāo de pequeno valor foi a Lei no 10.099, de 19-12-2000.

Ela definiu obrigação de pequeno valor para a Previdência Social e estabeleceu que tais obrigações poderão ser quitadas sem a necessidade de expedição de precatório.

Posteriormente, a Lei $n^{\circ} 10.259 / 01$ (Juizados Especiais da Justiça Federal) ${ }^{8}$ dispôs que o juiz passaria a ter o dever de determinar o seqüestro do numerário necessário, caso desatendida a requisição judicial.

A mesma lei também fixou que os créditos de pequeno valor para a Fazenda Pública da União seriam aqueles iguais ou inferiores a sessenta salários mínimos.

A EC no $30 / 2000$ acabou por gerar um efeito contrário à expectativa de incentivo de pagamento aos precatórios de caráter alimentício.

$\mathrm{O}$ art. 78 do ADCT, ao autorizar o parcelamento em 10 anos para os precatórios não-alimentícios, determinou que o não pagamento das parcelas resultaria no seqüestro judicial dos valores correspondentes.

Tal regra não abrangia a falta de pagamento dos precatórios alimentícios.

8 Lei $\mathrm{n}^{0} 10.259 / 2001$ :

Art. 17. Tratando-se de obrigaçāo de pagar quantia certa, após o trânsito em julgado da decisão, o pagamento será efetuado no prazo de sessenta dias, contados da entrega da requisiçāo, por ordem do Juiz, à autoridade citada para a causa, na agência mais próxima da Caixa Econômica Federal ou do Banco do Brasil, independentemente de precatório.

$\$ 1^{\circ}$ Para os efeitos do $\$ 3^{\circ}$ do art. 100 da Constituição Federal, as obrigaçōes ali definidas como de pequeno valor, a serem pagas independentemente de precatório, terão como limite o mesmo valor estabelecido nesta Lei para a competência do Juizado Especial Federal Cível (art. 3º, caput).

$\$ 2^{\circ}$ Desatendida a requisição judicial, o Juiz determinará o seqüestro do numerário suficiente ao cumprimento da decisão. 
Por isso, os governos estaduais passaram a dar prioridade de pagamento aos créditos de natureza não-alimentícia como forma de evitar o seqüestro de recursos públicos em detrimento do pagamento dos precatórios alimentícios, que, assim, somente passaram a ser pagos com os recursos residuais.

Em 12 de junho de 2002, a EC n 37 especificou como de pequeno valor, para efeito de dispensa de expedição de precatório, os débitos que tenham valor igual ou inferior a trinta salários mínimos, em se tratando de Município, e de quarenta salários mínimos em se tratando de Estados.

Eis suas principais mudanças:

(a) vedação da expedição de precatório complementar ou suplementar ou mesmo o seu fracionamento de forma a se enquadrar na hipótese das obrigações de pequeno valor prevista no $\$ 3^{\circ}$ do art. 100 da Constituição;

(b) o disciplinamento de regras relativas às obrigações de pequeno valor por meio dos novos arts. 86 e 87 do ADCT.

As modificações posteriores a 1988 tentaram dar soluções pontuais, de forma a assegurar, nos limites jurídicos, o cumprimento das sentenças judiciais e a garantir o direito daqueles que detêm crédito contra a Fazenda Pública.

Embora as modificações do regime de precatórios (EC nos 20, 30 e 37 e pela Lei $\mathrm{n}^{\mathrm{0}} 10.099$, de 19-12-00, e Lei $\mathrm{n}^{\mathrm{o}} 10.259$, de 12-6-01) tenham alterado a forma de pagamento dos precatórios resultantes de sentença judicial transitada em julgado pela Fazenda Pública, manteve-se como regra a expedição do precatório, somente dispensado quando se tratasse de obrigação de pequeno valor.

Em outras palavras, o regime genérico dos precatórios e seus vícios de origem permanecem rigorosamente os mesmos.

Embora tenham surgido formas alternativas de equacionar o problema do inadimplemento do Poder Público, a eventual solução nunca passou por uma remodelagem total da disciplina, mas apenas por alterações tópicas.

Apesar das mudanças, o regime de precatórios persiste com problemas de alta inadimplência, uma vez que não consegue dar tratamento adequado ao problema financeiro e político do Poder Público.

\section{O quadro atual dos precatórios no país}

O nāo pagamento de precatórios continuou apresentando relevância no cenário nacional.

O total de precatórios pendentes de pagamento, a preços de junho de 2004, é de 61 bilhōes, dos quais $73 \%$ se referem a débitos dos Estados ${ }^{9}$ (vide Tabela 1, a seguir).

Fonte e metodologia do Supremo Tribunal Federal. 


\section{Tabela 1}

\begin{tabular}{|c|c|c|}
\hline \multirow{2}{*}{$\mathbf{U F}$} & \multicolumn{2}{|c|}{ Total de Precatórios Pendentes } \\
\hline & Municipais & Estaduais \\
\hline $\mathbf{A C}$ & $47.221 .380,03$ & $109.979 .180,59$ \\
\hline $\mathbf{A L}$ & $149.025 .961,83$ & $55.234 .296,97$ \\
\hline AM & $116.574 .237,20$ & $36.513 .866,07$ \\
\hline AP & 2.635 .679 .27 & 27.325 .048 .67 \\
\hline BA & 518.521 .027 .17 & $557.687 .758,26$ \\
\hline CE & 90.176 .858 .94 & 469.872 .201 .42 \\
\hline DF & 10.098 .69 & 2.429 .178 .278 .08 \\
\hline ES & 1.090 .630 .121 .54 & $6.975 .143 .012,33$ \\
\hline GO & $140.250 .99 \mid .56$ & 906.816 .445 .84 \\
\hline MA & 75.149 .618 .51 & 72.155 .113 .82 \\
\hline MG & $733.456 .200,93$ & $3.000 .000 .000,00$ \\
\hline MS & 45.688 .795 .97 & $276.857,909.75$ \\
\hline MT & $375.279 .490,35$ & 2.223 .516 .346 .55 \\
\hline PA & 11.851 .165 .12 & 0,00 \\
\hline PB & $41.132 .608,23$ & $139.780 .416,80$ \\
\hline PE & $82.106 .953,07$ & $83.795 .301,56$ \\
\hline PI & $29.564 .852,85$ & $139.758 .47 \mid, 93$ \\
\hline PR & 4.560 .640 .552 .90 & $6.940 .496 .196,47$ \\
\hline RJ & 303.485 .459 .41 & $1.322 .801 .846,60$ \\
\hline $\mathbf{R N}$ & 176.178 .115 .93 & 112.409 .055 .17 \\
\hline RO & 122.175 .310 .98 & 318.822 .635 .00 \\
\hline $\mathbf{R R}$ & 6.558 .060 .42 & 2.043 .722 .09 \\
\hline RS & 194.399.508.30 & 2.329 .490 .913 .33 \\
\hline SC & $122.759 .411,02$ & $300.002 .604,38$ \\
\hline SE & 64.580 .151 .51 & $71.831 .233,96$ \\
\hline SP & 10.887 .306 .102 .85 & 12.224 .298 .357 .89 \\
\hline TO & $10.126 .502,26$ & $11.373 .963,94$ \\
\hline \multirow[t]{2}{*}{ TOTAL } & $19.997 .485 .216,84$ & 41.137 .184 .177 .47 \\
\hline & \multicolumn{2}{|c|}{$61.134 .669 .394,31$} \\
\hline
\end{tabular}

Notas: * A preços de junho de 2004.

** O valor dos precatórios municipais e estaduais de AL e dos precatórios municipais da BA contemplam apenas os valores referentes a Justiça do Trabalho.

Paralelamente ao não pagamento por parte de Estados e Municípios observase uma situação financeira difícil dos entes federados. 
Veja-se o quadro a seguir:

Situação Financeira dos Estados

\begin{tabular}{|c|c|c|c|c|c|c|}
\hline Estados & $\begin{array}{c}\text { Gasto com } \\
\text { Pessoal (2004) }\end{array}$ & Saúde & Educaçāo & Dívida & $\begin{array}{c}\text { Pessoal de } \\
\text { Educaçāo e } \\
\text { Saúde }\end{array}$ & $\begin{array}{c}\text { Total de } \\
\text { vinculaçōes }\end{array}$ \\
\hline$A C$ & 62.27 & 12 & 25 & 13 & -25 & 87.27 \\
\hline AL & 62.08 & 12 & 25 & 13 & -25 & 87,08 \\
\hline $\mathbf{A M}$ & 49.25 & 12 & 25 & 13 & -25 & 74,25 \\
\hline AP & 50.64 & 12 & 25 & 13 & -25 & 75,64 \\
\hline BA & 62.18 & 12 & 25 & 13 & -25 & 87.18 \\
\hline CE & 64,64 & 12 & 25 & 13 & -25 & 89.64 \\
\hline DF & 42.79 & 12 & 25 & 13 & -25 & 67,79 \\
\hline ES & 61.83 & 12 & 25 & 13 & -25 & 86,83 \\
\hline GO & 61.01 & 12 & 25 & 13 & -25 & 86.01 \\
\hline MA & 63,69 & 12 & 25 & 13 & -25 & 88.69 \\
\hline MG & 62,53 & 12 & 25 & 13 & -25 & 87.53 \\
\hline MS & 63.48 & 12 & 25 & 13 & -25 & 88.48 \\
\hline MT & 47.48 & 12 & 25 & 13 & -25 & 72.48 \\
\hline PA & 61.63 & 12 & 25 & 13 & -25 & 86.63 \\
\hline PB & 73.24 & 12 & 25 & 13 & -25 & 98,24 \\
\hline PE & 79.53 & 12 & 25 & 13 & -25 & 104.53 \\
\hline $\mathbf{P I}$ & 64.69 & 12 & 25 & 13 & -25 & 89,69 \\
\hline PR & 58.67 & 12 & 25 & 13 & -25 & 83.67 \\
\hline $\mathbf{R}$ & 53.71 & 12 & 25 & 13 & -25 & 78.71 \\
\hline RN & 65,64 & 12 & 25 & 13 & -25 & 90.64 \\
\hline RO & 55,36 & 12 & 25 & 13 & -25 & 80.36 \\
\hline $\mathbf{R R}$ & 41.49 & 12 & 25 & 13 & -25 & 66.49 \\
\hline RS & 72.94 & 12 & 25 & 13 & -25 & 97.94 \\
\hline SC & 59.41 & 12 & 25 & 13 & -25 & 84.41 \\
\hline SE & 61.88 & 12 & 25 & 13 & -25 & 86.88 \\
\hline SP & 57.16 & 12 & 25 & 13 & -25 & 82.16 \\
\hline TO & 45.83 & 12 & 25 & 13 & -25 & 70.83 \\
\hline MÉDIA & 59,45 & 12,00 & 25,00 & 13,00 & $-25,00$ & 84,45 \\
\hline
\end{tabular}

Os Estados apresentam uma média de comprometimento da Receita Corrente Líquida (RCL) de $84,45 \%$, incluindo gastos com a saúde, educação, pessoal e com o pagamento da dívida com a União.

Assim, do total de recursos dos estados, restam apenas $15,55 \%$ para outros gastos e investimentos.

No ano de 2004, o estoque de precatórios em atraso dos estados representou $23 \%$ da RCL destes.

Nos dados levantados pelo SUPREMO, observou-se que, nos últimos 5 anos, ocorreu um rápido crescimento do estoque de precatórios nas várias unidades da federação. 
Em parte tal se deu em decorrência do ingresso de novos precatórios, que têm apresentado taxas crescentes e, em parte, devido ao baixo nível de pagamentos efetuados pelos Estados e Municípios.

Atualmente, os Estados destinam aproximadamente 0,5\% da RCL para pagamento de precatório.

Já o fluxo anual de novos precatórios, em torno de $R \$ 3,2$ bilhōes ao ano, representa cerca de $2 \%$ da RCL destes, ou seja, o valor destinado para pagamento nāo é suficiente para equacionar nem os novos ingressos de precatórios (vide Tabela 2).

Tabela 2

\begin{tabular}{|c|c|c|c|c|c|c|}
\hline UF & $\begin{array}{c}\text { Estoque de } \\
\text { Precatório [A] }\end{array}$ & $\begin{array}{l}\text { Pagto. de } \\
\text { Precatórios em } \\
2003 \text { [B] }\end{array}$ & $\begin{array}{l}\text { Despesa Primária } \\
\text { Líquida (2004) [C] }\end{array}$ & {$[B / C]$} & Fluxo [D] & Anos \\
\hline $\mathbf{A C}$ & & 239.700 .00 & 1.163 .535 .651 .28 & $0.02 \%$ & $2.100 .000,00$ & Infinito \\
\hline $\mathbf{A L}$ & 4.296 .97 & 20.982 .435 .00 & 115.847 .007 .82 & $0,99 \%$ & $.026 .32 \downarrow .02$ & \\
\hline$A M$ & .513 .866 .07 & .55 & 521.382 .634 .31 & $0.12 \%$ & 322.761 .81 & \\
\hline AP & .325 .048 .67 & 673.688 .00 & 46.239 .723 .17 & $0,07 \%$ & 2.486 .579 .43 & Infinito \\
\hline BA & 7.687 .758 .26 & 10.404 .041 .00 & 9.789 .561 .537 .01 & $0.11 \%$ & $99.693 .939,00$ & Infinito \\
\hline CE & 201.42 & 7.24 & 5.287 .482 .388 .99 & $0.19 \%$ & $24.542 .113,74$ & Infinito \\
\hline DF & & 2.659 .611 .06 & 5.596 .741 .000 .00 & $0.05 \%$ & $141.781 .169,22$ & Infinito \\
\hline ES & 6.975 .143 .012 .33 & & 3.504 .966 .735 .78 & $0.00 \%$ & 634.738 .014 .12 & Infinito \\
\hline GO & 06.816 .445 .84 & 9.872 .487 .00 & 5.579 .266 .078 .74 & $0.18 \%$ & $55.600 .000,00$ & Infinito \\
\hline MA & & & 2.19 & $0.07 \%$ & 5.36 & Infinito \\
\hline MG & 3.000 .000 .000 .00 & 183.962 .562 .00 & 15.753 .584 .132 .14 & $1.17 \%$ & 0.00 & Infinito \\
\hline MS & 6.857 .909 .75 & 21.010 .637 .21 & 2.935 .059 .626 .46 & $0.72 \%$ & 25.194 .069 .79 & Infinito \\
\hline MT & 3.516 .346 .55 & $12.728 .806,00$ & 365.821 .748 .94 & $0.38 \%$ & 202.339 .987 .54 & Infinito \\
\hline PA & 0.00 & 30.752 .793 .00 & 147.353 .104 .43 & $0.74 \%$ & 0.00 & \\
\hline PB & 139.780 .416 .80 & 804.459 .00 & 2.502 .914 .774 .81 & $0.31 \%$ & 14.348.042,39 & Infinito \\
\hline PE & 83.795 .301 .56 & 4.413 .813 .26 & 6.344 .939 .731 .32 & $0.07 \%$ & $16.410 .245,58$ & Infinito \\
\hline PI & 9.758 .471 .93 & .289 .00 & 1.955 .575 .233 .17 & $0.70 \%$ & I 3.679.275,50 & Infinito \\
\hline PR & 6.940 .496 .196 .47 & 42.433 .063 .00 & 7.935 .737 .887 .88 & $0.53 \%$ & $303.545 .757,8 \mathrm{I}$ & Infirito \\
\hline RJ & 1.322 .801 .846 .60 & 299.321 .684 .00 & 21.112 .100 .079 .37 & $1.42 \%$ & $157.952 .612,89$ & \\
\hline RN & 2.409 .055 .17 & 23.759 .371 .00 & 2.515 .956 .840 .75 & $0.94 \%$ & 10.229 .224 .02 & \\
\hline RO & 318.822 .635 .00 & 3.468 .993 .00 & 728.983 .110 .18 & $0,48 \%$ & 29.012 .859 .79 & Infirito \\
\hline $\mathbf{R R}$ & 2.043 .722 .09 & 340.029 .00 & 487.518 .129 .36 & $0.07 \%$ & $369.256,56$ & Infinito \\
\hline RS & $2.329 .490 .913,33$ & 2.580 .317 .33 & 11.098 .892 .702 .14 & $0.11 \%$ & $286.473 .208,33$ & Infinito \\
\hline SC & 300.002 .604 .38 & $24.422 .700,00$ & 5.394 .502 .634 .68 & $0.45 \%$ & $2.998 .239,17$ & 1 \\
\hline SE & 71.831 .233 .96 & $12.341 .100,00$ & 2.125 .518 .561 .96 & $0.58 \%$ & $4.104 .914,29$ & \\
\hline SP & 12.224.298.357.89 & 1.191 .733 .172 .02 & 46.400 .532 .569 .91 & $2.57 \%$ & $918.881 .794,20$ & 43 \\
\hline TO & 11.373 .963 .94 & $1.900 .261,00$ & 1.856 .648 .564 .36 & $0.10 \%$ & 729.039 .85 & I \\
\hline TOTAL & $41.137 .184 .177,47$ & $1.947 .283 .362,73$ & $176.712 .880 .041,15$ & $0,49 \%$ & $3.280 .625 .541,40$ & \\
\hline
\end{tabular}

Valores referentes a 2004

Valores enviados pelos estados em negrito. 
Na medida em que a questão não apresenta perspectivas de solução, a tensão entre o Poder Judiciário, credores de precatórios e os Entes da Federação tem aumentado.

Na verdade, tanto credores quanto Poder Público têm apresentado argumentos igualmente legítimos e importantes para a defesa de seus interesses e preocupações.

Frente às dificuldades, o Poder Judiciário tem deferido pedidos de seqüestro para o pagamento de precatórios, o que tem levado as contas públicas ao caos financeiro à medida que os seqüestros são efetuados sem distinção do tipo de recurso.

Exemplo destas questões são algumas prefeituras de São Paulo que tiveram as merendas suspensas em suas escolas e folhas de pagamentos atrasadas por conta destes seqüestros.

Outro tipo de decisão proferida pelo Judiciário é admitir o pagamento de tributos correntes com precatórios sem que haja lei autorizadora ou sem que haja planejamento fiscal prévio, o que leva a uma redução não prevista da arrecadação dos Estados e Municípios.

Observa-se que a busca para dar cumprimento às sentenças judiciais e do próprio art. 100 tem conduzido a decisões que, em alguns casos, provocam caos no âmbito das Administrações locais, pois não consideram os problemas financeiros estruturais que prefeituras e governos estaduais enfrentam nos últimos anos.

Os Entes Federados, cientes de sua responsabilidade institucional, também têm buscado soluções para o problema dos precatórios no âmbito de cada governo.

Com o objetivo de reduzir seus estoques de precatórios alguns Estados instituíram mecanismos para pagamento de dívida ativa com precatórios (Paraná e São Paulo).

A partir das dificuldades apresentadas, o Supremo Tribunal Federal, sob a minha presidência, iniciou uma série de estudos e discussões com as partes envolvidas, com o objetivo de alcançar uma proposta que equacionasse o problema.

Atualmente encontra-se no Senado Federal proposta de Emenda Constitucional que é fruto do trabalho por nós desenvolvido.

O projeto objetiva compatibilizar a capacidade de pagamento dos entes federados com a necessidade e o direito de recebimento por parte dos credores.

Equaciona débitos existentes e assegura o pagamento dos novos precatórios.

A proposta cria uma vinculação orçamentária para o pagamento de precatórios.

A partir deste montante ${ }^{10}$ é feita uma distribuição de recursos para a "fila" (30\%) e para leilões de compra de precatórios pelos entes federados (70\%).

Propõe-se novo ordenamento da "fila", agora por ordem de valor, o que objetiva proporcionar maior justiça social com os credores de precatório de menor valor, que são em grande parte os alimentares.

10 O montante proposto é superior ao atualmente gasto com precatórios em todos os estados da federaçāo. 
A nova ordenação garante que os precatórios de menor valor sejam prontamente pagos pelo poder público, não tendo, portanto, interrupções de pagamento oriundas do "trancamento da fila".

No modelo atual, por ordem cronológica, quando um precatório de valor elevado é o primeiro na ordenação, os pagamentos são interrompidos, caso o Estado ou Município não tenha recursos suficientes para pagar aquele precatório específico.

A nova sistemática permitirá que os precatórios de menor valor possam ter pronto pagamento, o que vai de encontro com os preceitos constitucionais que asseguram tratamento diferenciado aos de pequeno valor ( $\mathrm{CF}$, art. 100, $₫ 3^{\circ}$ ).

Adiciona-se o fato de que os precatórios de natureza nāo-alimentar apresentam, em média, um valor até duas vezes maior do que os de natureza alimentar, o que irá proporcionar aos precatórios alimentares prioridade de pagamento.

A proposta prevê, ainda, a criação de leilões para a venda de precatórios ao ente federado.

Abre-se aqui a possibilidade do credor ter sua quitação imediata e por outro lado que o ente federado possa usufruir do deságio existente no mercado, hoje apropriado por instituições financeiras, grandes escritórios de advocacia e empresas que negociam precatórios.

O mecanismo de leilões, conjugado à nova ordenação por critério crescente de valor, produzirá uma solução rápida e justa para a questão.

A situação atual, em que o valor do fluxo anual de novos precatórios é superior ao valor anualmente pago de precatórios pelo estado, gera uma situação que só tende a se agravar no longo prazo, aumentando cada vez mais o estoque de precatórios pendentes de pagamento.

Em outras palavras, numericamente o estoque de precatórios tenderá para infinito na maioria dos estados se nada for feito em relação à situação atual.

Estudo realizado pela equipe do SUPREMO indica que a nova proposta, em média, deverá resolver a questão nos Estados da Federação em no máximo 13 anos.

Se permanecermos na situação atual a tendência é de que o estoque de precatórios cresça indefinidamente.

No novo modelo, estados como Rio de Janeiro resolveriam a situação em cerca de 3 anos, enquanto que São Paulo levaria cerca de 20 anos.

\section{Conclusão}

A possibilidade de inclusão de um artigo ao Ato das Disposiçōes Constitucionais Transitórias (ADCT), instituindo um sistema alternativo para o pagamento de precatórios, representa um importante avanço de mérito na questão de precatórios. 
Cria-se a possibilidade para que os entes federados possam honrar o pagamento de suas dívidas judiciais.

As mudanças propostas, como a ordenaçāo da fila por ordem de valor, irāo trazer grande justiça social para o sistema, uma vez que beneficiarão os precatórios de menor valor, a saber, os alimentares.

A previsão de pagamento a vista por meio de leilões permitirá que o credor tenha uma saída imediata para seu crédito sem que tenha que arcar com os elevados deságios hoje existentes.

A vinculação de parte das despesas dos entes federados para o pagamento de precatórios irá garantir um fluxo certo e contínuo para o pagarnento destes.

Destaco que o critério da ordem crescente de valor, aplicável a $30 \%$ dos recursos vinculados, privilegiará os titulares dos chamados créditos alimentícios e representa, na grande maioria dos estados, um volume de recursos superior ao hoje destinado para o pagamento de precatórios nos estados.

Não é razoável sob o aspecto político, moral e lógico que, em um processo de execução forçada, como é o caso do processo de execução para pagamento de precatório, possa o devedor condenado deixar de pagar sem sofrer qualquer tipo de punição.

Tampouco podemos fechar os olhos para os graves problemas econômicos que afligem Estados e Municípios, ou mesmo obrigar que estes deixem de honrar compromissos constitucionais, como folha de pagamento, saúde e educação, com o intuito de honrar outros compromissos.

É preciso achar o caminho do "meio" para que cidadão e credor, pessoas que muitas vezes se confundem, possam ter seus direitos de cidadão (saúde, educação e segurança, dentre outros) e de credor preservados frente à Constituição.

\section{PROPOSTA DE EMENDA À CONSTITUIÇÃO}

Acrescenta o $\$ 7^{\prime \prime}$ ao art. 100 da Constituição Federal e o art. 95 ao Ato das Disposições Constitucionais Transitórias, instituindo regime especial de pagamento de precatórios pela União, Estados, Distrito Federal e Municípios.

As Mesas da Câmara dos Deputados e do Senado Federal, nos termos do $\$ 3^{\circ}$ do art. 60 da Constituição Federal, promulgam a seguinte Emenda ao texto constitucional:

Art. 1o O art. 100 da Constituição Federal passa a vigorar acrescido dos seguintes parágrafos:

“ $\$ 7^{\circ}$ Os pagamentos de precatórios somente ocorrerão após prévia compensação de valores nas hipóteses em que o credor originário possuir débitos inscritos em dívida ativa da respectiva Fazenda Pública: 
I - com execução fiscal não embargada; ou

II - com trânsito em julgado de sentença favorável à Fazenda Pública em embargos à execução fiscal."

Art. 2o O Ato das Disposições Constitucionais Transitórias passa a vigorar acrescido do seguinte artigo:

“Art. 95. A União, os Estados, o Distrito Federal e os Municípios poderão optar, por ato do poder executivo, de forma irretratável, por regime especial de pagamento de precatórios relativos às suas administraçōes direta e indireta, a ser efetuado com recursos calculados com base na vinculação de percentual de suas despesas primárias líquidas, nos termos, condições e prazos definidos em lei federal.

$\$ 1^{\circ}$ Os recursos aplicados no pagamento de precatórios serão equivalentes, no mínimo, a três por cento da despesa primária líquida do ano anterior para a União, os Estados e o Distrito Federal e um e meio por cento da despesa primária líquida do ano anterior para os Municípios.

$\$ 2^{\circ}$ Cinqüenta por cento, no mínimo, dos recursos de que trata o $\$ 1^{\circ}$ serão liberados até o último dia do mês de abril e os valores restantes serão liberados até o último dia do mês de setembro de cada ano.

$\$ 3^{\circ}$ A disponibilização de que trata o $\$ 2^{\circ}$ ocorrerá por meio do depósito em conta especial, criada para tal fim, e os recursos não poderão retornar para a livre movimentação do Ente da Federação.

$\$ 4^{\circ}$ Os recursos de que trata o $\$ 1^{\circ}$ serão distribuídos da seguinte forma:

I - setenta por cento serão destinados para leilóes de pagamento a vista de precatórios; e

II - trinta por cento serão destinados para o pagamento dos precatórios não quitados por meio de leilão de que trata o inciso I.

$\mathbb{5} 5^{\circ}$ O leilão de que trata o $\$ 4^{\circ}$, inciso I, ocorrerá por meio de oferta pública a todos os credores de precatórios habilitados pelo respectivo Ente da Federaçāo.

$\$ 6^{\circ}$ A habilitação somente ocorrerá para os precatórios em relação aos quais não esteja pendente, no âmbito do Poder Judiciário, recurso ou impugnação de qualquer natureza.

$\$ 7^{0} \mathrm{Na}$ hipótese do $\ 4^{2}$, inciso II, a ordem de pagamento respeitará os seguintes critérios:

I - ordem crescente dos valores atualizados, devidos a cada credor dos precatórios, sendo quitados, sempre com prioridade, os de menor valor, independentemente da data de apresentação; e

II - no caso de identidade de valores, a preferência será dada ao credor do precatório mais antigo.

$\$ 8^{\circ}$ Para os fins do $\mathbb{4} 4^{\circ}$, inciso II, existirá uma fila única de pagamentos de precatórios, a ser gerenciada pelo Tribunal de Justiça local, ou, no caso da União, 
pelo Superior Tribunal de Justiça, na qual se incluirão débitos relativos às entidades públicas que se sujeitam ao regime dos precatórios.

$\$ 9^{9}$ A opção do Ente da Federação pelo regime especial de pagamento de precatórios prevista no caput deste artigo afasta, transitoriamente, enquanto estiver sendo cumprida a vinculação de recursos, a incidência dos arts. 34, VI; 36 , II; 100, caput, $\mathbb{S} 1^{\circ}, 1^{\circ}-\mathrm{A}, 2^{\circ}, 4^{\circ}$ e $5^{\circ}$ da Constituição, bem como o art. 78 deste Ato das Disposições Constitucionais Transitórias, inclusive quanto a seqüestros financeiros já requisitados ou determinados na data da opção.

$\$ 10$. Os precatórios parcelados na forma do art. 78 deste Ato das Disposiçōes Constitucionais Transitórias e ainda pendentes de pagamentos ingressarão automaticamente no regime especial de pagamento de acordo com o valor consolidado das parcelas não pagas relativas a cada credor.

$\$ 11$. No caso de opção pelo regime especial de pagamento e de não liberação tempestiva dos recursos, haverá o seqüestro por ordem do Presidente do Tribunal de Justiça local ou, no caso da União, do Presidente do Superior Tribunal de Justiça, até o limite do valor não liberado.

$\$ 12$. Na hipótese do $\$ 11$, o Chefe do Poder Executivo responderá por crime de responsabilidade.

$\$ 13$. Para os fins do regime especial de pagamento, será considerado o valor do precatório, admitido o desmembramento por credor.

$\$ 14$. No caso de desmembramento do precatório conforme previsto no $\$ 13$, não se aplica aos valores por credor o art. $100, \mathbb{3} 3^{\circ}$, da Constituição.

$\$ 15$. Os precatórios habilitados poderāo ser utilizados, a critério do Ente da Federação, para o pagamento de débitos inscritos em dívida ativa até 31 de dezembro de 2004, sem que isso signifique quebra da ordem de pagamento de que trata o $\$ 4^{\circ}$, inciso II.

$\$ 16$. Os precatórios pendentes de pagamento serão corrigidos, a partir da data da promulgação desta Emenda Constitucional, pelo Índice de Preços ao Consumidor Amplo - (IPCA) ou outro que o venha a substituir, calculado pelo Instituto Brasileiro de Geografia e Estatística (IBGE), acrescidos de juros de seis por cento ao ano, ficando excluída a incidência de juros compensatórios."

Art. 3ํ Lei aprovada pelo Congresso Nacional regulamentará a matéria tratada nesta Emenda e será de observância obrigatória para os Estados, Distrito Federal e Municípios que aderirem a este regime.

Art. $4^{\circ} \mathrm{O}$ regime especial de pagamento de precatórios vigorará enquanto o valor dos precatórios devidos e não pagos for superior ao valor dos recursos vinculados nos termos do $\$ 1^{\circ}$ do art. 95 do Ato das Disposiçōes Constitucionais Transitórias.

Parágrafo único. O Ente da Federação voltará a observar o disposto no art. 100 da Constituição, no ano seguinte ao que ficar constatado que o valor dos 
precatórios devidos e não pagos é inferior aos recursos vinculados nos termos do

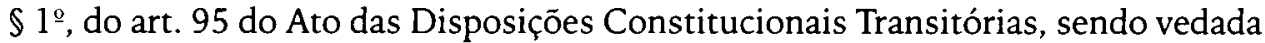
nova adesão ao regime especial.

Art. 5 A opção em aderir ao regime de pagamento criado pelo art. 95 do Ato das Disposiçōes Constitucionais Transitórias deverá ocorrer em até cento e oitenta dias contados da publicação da lei que regulamentar esta Emenda Constitucional e será irretratável.

Art. $6^{\circ}$ Esta Emenda Constitucional entra em vigor na data de sua publicação.

\section{JUSTIFICAÇÃO}

A questão de precatórios assumiu relevância no cenário nacional a partir do enorme volume de precatórios não pagos por parte dos Estados e Municípios. O total pendente de pagamento a preços de junho de 2004 é de 61 bilhões, dos quais 73\% se referem a débitos dos Estados.

Paralelamente a esta situação, Estados e Municípios apresentam uma situação financeira difícil. Os Estados apresentam uma média de comprometimento da receita corrente líquida de $85 \%$ (pessoal, saúde, educação e pagamentos de dívidas), ou seja, do total de recursos dos estados restam apenas $15 \%$ para outros gastos e investimentos.

Esta proposta de emenda à Constituição é apresentada como sugestão para viabilizar o debate na busca de uma soluçāo para a questão de precatórios.

Durante o ano de 2005 foram realizadas reuniōes com todos os segmentos objetivando minimizar conflitos e buscar uma solução comum a todos os envolvidos.

Esta proposição busca contribuir para uma solução definitiva para a questão, equacionando os débitos existentes e ao mesmo tempo assegurando o pagamento dos novos precatórios.

Sala das Sessōes, de março de 2006. 